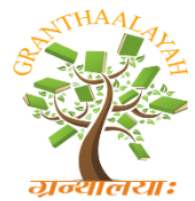

\author{
INTERNATIONAL JOURNAL OF RE
GRANTHAALAYAH \\ A knowledge Repository
}

Social

\title{
INVESTMENT SCHEME IN KERTAJATI AEROCITY DEVELOPMENT IN MAJALENGKA DISTRICT, WEST JAVA PROVINCE WHICH IS ORIENTED TO THE PRINCIPLES OF GOOD CORPORATE GOVERNANCE
}

\author{
Ratna Januarita ${ }^{* 1}$, Frency Siska ${ }^{2}$, Eka An Aqimuddin ${ }^{3}$ \\ ${ }^{* 1,2,3}$ Faculty of Law, Universitas Islam Bandung, Indonesia
}

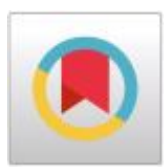

\begin{abstract}
In the National Medium-Term Development Plan 2015-2019 especially in West Java Province, namely the construction of Kertajati Airport, located in Majalengka Regency. Therefore, the West Java provincial government has drawn up Regional Regulation No. 13 of 2010 concerning the Development and Development of West Java International Airport and Kertajati Aerocity. Kertajati Aerocity will carry out its duty to promote and strengthen the creation of an engine of economic growth in the western part of Indonesia that will involve the participation of local governments, the central government, investors and the community. So, the purpose of this article is to analyze the investment scheme in the development of Aerocity Kertajati in Majalengka Regency which is oriented to the principles of good corporate governance. The conclusion of this article is the Investment Scheme in Kertajati Aerocity Development in Majalengka Regency, West Java, namely through cooperation between PT BIJB and investors (land authorities) in terms of land acquisition and development cooperation relationships and development of the Aerocity Kertajati area. Investment Scheme in Kertajati Aerocity Development in Majalengka Regency, West Java Oriented Principles of Good Corporate Governance namely by implementing Good Government Governance, namely the government as one of the parties in its role of building and developing the Aerocity Kertajati area must refer to good values, clean and fair, and Good Corporate Governance must be reflected in the management of PT BIJB's business activities as an extension of the West Java provincial government covering transparency, accountability, responsibility, independence, and justice.
\end{abstract}

Keywords: Airport; GCG; Kertajati Aerocity; Development; And Welfare.

Cite This Article: Ratna Januarita, Frency Siska, and Eka An Aqimuddin. (2019). "INVESTMENT SCHEME IN KERTAJATI AEROCITY DEVELOPMENT IN MAJALENGKA DISTRICT, WEST JAVA PROVINCE WHICH IS ORIENTED TO THE PRINCIPLES OF GOOD CORPORATE GOVERNANCE." International Journal of Research Granthaalayah, 7(10), 191-204. https://doi.org/10.29121/granthaalayah.v7.i10.2019.387. 


\section{Introduction}

In the 2015-2019 National Medium-Term Development Plan as stipulated in Presidential Regulation No. 2 of 2015, it is stated that one of the National Medium-Term Strategic Activities of West Java Province is the construction of Kertajati Airport, located in Majalengka Regency. To carry out this mandate, the West Java provincial government has drawn up Regional Regulation No. 13 of 2010 concerning the Development and Development of West Java International Airport and Kertajati Aerocity. The Regional Regulation explains important principles in the development and development of West Java International Airport and Kertajati Aerocity, namely the principle of space utilization for all stakeholders in an integrated, efficient, effective, harmonious, harmonious, balanced and sustainable manner [1]. The aims and objectives of the development and development are to: a) encourage the development of the Ciayumajakuning development area (Cirebon-Indramayu-Majalengka-Kuningan); b) increase regional economic growth based on Regional potential; c) increase the global competitiveness of West Java in order to accelerate investment growth; d) improve services to the public in the field of air transportation; and e) increase investment, industry, trade, tourism, housing and employment expansion [2].

As the next concrete step, the West Java provincial government established a Regionally Owned Enterprise (BUMD), namely PT West Java International Airport (PT BIJB) based on West Java Province Regional Regulation Number 22 of 2013 concerning the Establishment of a Regionally Owned Business Enterprise managing the West Java International Airport and Kertajati Aerocity. The establishment of this BUMD aims to: a) carry out the operation of West Java International Airport and develop Kertajati Aerocity in a sustainable manner; b) developing Regional investment; c) contributing to the Original Local Revenue; d) move the regional economy; and e) providing services to the community.

Information relating to the development and development of the airport and Kertajati Aerocity on the website of PT BIJB is said to have progressed in development which is expected to be completed in 5 (five) important stages, namely: Preparation Phase (2015); Phase I (2015-2020) which will focus on airport development and development; Phase I-II (2016-2025) will focus on the development of Kertajati Aerocity; Phase III (2025-2035) will focus on the growth of Kertajati as an aerotropolis; Phase IV (2035-2045) will place Kertajati Aerocity as an actor and manager of economic sustainability in the region, especially in Ciayumajakuning [3]. It was also explained that Kertajati Aerocity would function as an industrial corridor that had direct access to Karawang and Bandung Regencies which were industrial estates. In the following description, it was also mentioned that Kertajati Aerocity would carry out its task to promote and strengthen the creation of an engine of economic growth in western Indonesia that would involve the participation of local governments, the central government, investors, and the community. It is hoped that in the future, Kertajati Aerocity will create and increase local people's income and purchasing power, improve the welfare of the community, create a local business climate, create jobs, encourage the growth of the local economy, strengthen the development of industry, business and the tourism sector, encourage the cultivation of resources nature, increase tax income, and so on. In relation to investment, the development of Kertajati Aerocity will create strategic access for investors for market access, security, safety and cost reduction, and can be the production base of its investment. 
Considering the very large funding requirements to realize the ideals and plans of the mega project, the financing framework will be pursued through the APBN, APBD and investment mechanism (partnership or cooperation with various parties) [4]. Related to investment opportunities in the development of BIJB and Kertajati Aerocity, it has attracted interest from a number of international investors to participate in the development series. Among others, Chinese SOEs engaged in the field of aerospace manufacturers, namely the Commercial Aircraft Corporation of China (COMAC). The company has expressed interest in investing in building a maintenance, repair and overhaul (MRO center) center that is expected to require trillions of rupiah. COMAC has also requested the West Java provincial government to facilitate the provision of about 43 hectares of land to be able to accommodate 200 aircraft that would later carry out maintenance, repairs and engine downtime [5]. In addition, there are finance companies that have expressed interest, namely China Aircraft Leasing Group (CALC) [6]. For the development and development of the industrial area in Kertajati Aerocity, other Chinese companies have submitted offers of cooperation, namely China Fortune Land Development Co. Ltd. (CFLD) [7].

The investment framework in a development should be designed by taking into account a number of important aspects including various aspects relating to the interests of the community whose land is acquired for development, sustainability and sustainability of life, environmental preservation and environmental carrying capacity, equal opportunities for domestic and foreign investors, a conducive legal framework, provision of social and public facilities, and empowerment of the surrounding community in various aspects [8].

Crucial matters such as this have not yet been found in studies and studies, both through information on the BIJB website, the direction and policies of the provincial government, as well as the regulatory framework that is relevant to investment and regional autonomy. Whereas on the other hand, by observing the presence of a number of potential foreign investors who are interested in investing their capital in the BIJB and Kertajati Aerocity mega projects, the framework and scheme to accommodate these important aspects and the legal vacuum related to investment cannot be postponed. Moreover, specifically for the construction of the BIJB, it is scheduled to finish and begin operations (landing and take off) in mid 2017. Considering that the construction of the BIJB and Kertajati Aerocity is estimated to require investments of tens of trillions of rupiah or more, if the preparation of the investment framework and scheme is delayed or late, it is feared it will reduce investor confidence that this mega project was built with the best possible preparation and the local government does not have sufficient time to prepare a fundamental framework that can accommodate a number of important aspects above.

Institutionally, the development and development of Kertajati Aerocity is carried out under the responsibility of the Governor and forms a management body, namely PT BIJB. In connection with the plan to open investment doors in the development of BIJB and Kertajati Aerocity, the principles of good corporate governance, which include the principles of transparency, accountability, responsibility, independence, and fairness are made as the main orientation and corridor to achieve the constitutional mandate, namely the fair society and prosperous. Thus, the development of this mega project in Kertajati will involve many aspects that demand the West Java provincial government and PT BIJB to be very careful in accommodating the interests of stakeholders and maintaining the balance of various related parties. 
Based on the above problem, the writer is interested to study it with the first problem, how is the investment scheme in the development of Aerocity Kertajati in Majalengka Regency, West Java? and how is the investment scheme in the development of Aerocity Kertajati in Majalengka Regency, West Java, which is oriented to the principles of good corporate governance?

\section{Results and Discussions}

\section{Investment Scheme in Kertajati Aerocity Development in Majalengka Regency, West Java}

The development of Aerocity Kertajati has 2 investment houses with its own interests but is related to one another. The first investment house is that in the field there is a condition of a large amount of land that has been controlled by a number of parties called the Land Authority and later described earlier as an Investor. With the limited financial capacity of the Company to be able to acquire land, the existence of the Land Authority that controls the area of the land provides a strategic benefit for the Company. In this case, land tenure by the Land Authority can be recorded as a process of land acquisition in the context of the development and development of the Kertajati Aerocity Area. In other words, the Land Authority acts as an Investor and functions to carry out financial bridging in terms of land acquisition for development projects and area development.

In addition, although PT BIJB has limited financial resources to acquire land and has not been able to control the land, PT BIJB already has an area management permit to be built and developed into the Kertajati Aerocity Area. This license is an advantage for the Company in determining bargaining positions with Investors. That is, the investor can not do much by just controlling the land alone, considering to be able to develop and develop land as an area that has continuity the absolute benefits of having a permit first [9]. On the contrary, PT BIJB is not enough to only have permission to build and develop it, considering the land factor is an essential and absolute factor in the development and development of a project. To obtain the required land, PT BIJB through PT BIJB AD already has a Location Permit which is one of the conditions for companies formed in the context of investment (investment) to obtain the land needed to carry out its capital investment plans. The establishment of PT BIJB AD as a subsidiary of PT BIJB is theoretically the second form of investment in a series of aerocity development investment schemes.

However, Article 2 Paragraph (3) Regulation of the Minister of Agrarian Number 5 Year 2015 states that the Location Permit is not necessary and is deemed owned by the company concerned in terms of: 1) The land to be acquired is an income from shareholders; 2) The land to be acquired is the land that has been controlled by another company in the framework of continuing the implementation of part or all of the planned investment in the capital of another company, and for that purpose an approval has been obtained from the authorized agency; 3) The land to be acquired is needed in order to carry out industrial business in an industrial area; 4) The land to be obtained originates from the authority or the organizer of the development of an area in accordance with the spatial plan of the development area; 5) The land to be acquired is needed for business expansion which is already in progress and for that expansion, a business expansion permit has been obtained in accordance with the applicable provisions, whereas the location of the land is adjacent to the business location in question; 6) The land needed to carry out the investment plan is not more than $25 \mathrm{Ha}$ (twenty-five hectares) for agricultural business and not more than $10,000 \mathrm{M}^{2}$ (ten thousand square meters) for non-agricultural business; or 7) The land that will be used to carry out the investment plan is the land that is already owned by the company concerned through the transfer 
of rights from another company, provided that the land is located in a location according to the applicable Regional Spatial Plan intended for use in accordance with investment plan concerned.

Continuing these provisions, Majalengka District Regulation Number 11 of 2011 concerning the Spatial Plan of Majalengka Regency Year 2011-2031 regulates a number of provisions that become the legitimacy of the development and development of the Kertajati Aerocity Region. Thus, it is necessary to establish a strategic partnership between PT BIJB and Investors so that the parties can jointly play a positive role and in accordance with applicable law for the development and development of the Kertajati Aerocity Area.

The form of cooperation that can be offered between PT. BIJB AD with investors (land authorities) theoretically as follows: 1) Joint Operation (KSO) or Joint Venture (JV): KSO or JV is created based on the agreement of the parties, without forming a new entity. Accordingly, the agreement which was prepared specifically regulates the agreement relating to the distribution of profits and losses from the project which is carried out jointly by the parties proportionally; 2) Joint Venture (PP) or Joint Enterprise (JE): PP or JE is done by forming a new company, generally in the form of a Limited Liability Company (PT) established by the parties as its shareholders. In the perspective of investment, this form of cooperation is referred to as direct investment. This means that the parties who are shareholders will jointly bear the profits and losses of the company's performance proportionally with reference to the Company Law and other applicable and relevant laws and regulations; 3) Build, Operate and Transfer (BOT): In this BOT model concession rights are granted to private entities from the government or other private parties to finance, design, build, and operate the facilities stated in the concession agreement, then transferred to the project provider on specified time. The recipient of the work will benefit when operating the facility within the agreed time frame. This BOT is common in construction projects; 4) Build, Operate and Own (BOO): In this model concession rights are granted to private entities from the government or other private parties to finance, design, build, and operate the facilities stated in the concession agreement, then owned by the recipient of the work. The employer will benefit when the recipient operates the facility within the agreed time frame and revenue sharing format. Thus, ownership of the promised facility or object will only shift from the employer to the recipient at the end of the concession period. This BOO model is common in construction projects; 5) Build, Operate, Own and Transfer (BOOT): BOOT is a project financing model that is a combination of BOT and BOO, which gives concession rights to private entities from the government or other private parties to finance, design, build, operate facilities and own them which is stated in the concession agreement, then is transferred to the project provider at the specified time; 6) Turn-key Agreement (TKA): In this collaboration model, the party receiving the work undertakes the project from start to finish comprehensively. At the agreed time, the employer or the project owner will receive the object of the agreement in full and is complete. This TKA is common in construction projects, but can be applied to other non-construction projects; 7) Technical Assistant (TA): This model is usually applied in connection with the purchase of a product or service product package. To help the buyer of the product, the seller will offer a technical assistance package so that the product buyer can run or use the product he bought. For example the purchase of machinery, aircraft, software, systems, factory construction, etc .; 8) Franchise or Franchise: In this model, the franchisee is given the right to utilize and / or use intellectual property rights or inventions or characteristics that are owned by the franchisor; 9) Leasing (SGU) or Leasing: This model is a corporate financing activity in the form of providing capital goods that will be used by a company for a certain period of time. 
At the end of the SGU term, the recipient of the SGU is given 3 (three) options: extend the rental period, the buyer of the goods that are the object of the SGU, or not continue the SGU; 10) Partnership: This model is commonly used in cooperative relationships with communities classified as micro, small and medium enterprises (MSMEs) or non-profit institutions, for example institutions engaged in social, community or religious affairs..

Based on the form of cooperation above, the strategic cooperation between the company and investors in investment development and development of the kertajati aerocity area, referring to Majalengka District Regulation Number 11 of 2011 concerning Spatial Planning for Majalengka Regency Year 2011-2031, it can be seen the position of Kertajati Sub-District which is the location the main development of the West Java International Airport and the Kertajati Aerocity Region, is a "perfect" area. In Chapter V of the Regional Regulation, especially those that regulate Regency Spatial Plan Plans, Kertajati District does not include vulnerable areas and geological protected areas.

In addition, in the RPJPD, RPJMD, Regional Regulation on RTRW, Strategic Plan, and other strategic provisions relating to the development and development of the Kertajati Aerocity Area, it can be clearly identified that the Kertajati mega project is a long-term project. Investors who pay attention to aspects of income sustainability as a major factor in their business activities, will fully consider becoming a strategic partner for PT BIJB or PT BIJB AD. This prospective and profitable business continuity should be considered by the parties in deciding cooperation models, especially in the context of land acquisition.

Potential aspects and prospects of the Kertajati Aerocity area can be packaged in a business framework with a special format for land acquisition. Of course, for the business framework for land acquisition to have a legal basis, it must pay attention to applicable and relevant legislation. Land acquisition cooperation between PT BIJB or PT BIJB AD (the Company) with Investors, can use several alternative cooperation patterns in the following Table 1 below:

Table 1: Alternative Pattern of Land Procurement Cooperation between PT BIJB or PT BIJB AD and Investors

\begin{tabular}{|c|c|c|c|}
\hline \multirow[t]{2}{*}{ NO. } & \multirow{2}{*}{$\begin{array}{c}\text { PARTNERSHIP } \\
\text { PATTERN }\end{array}$} & \multicolumn{2}{|c|}{ PARTNERSHIP RELATIONSHIP } \\
\hline & & $\begin{array}{l}\text { PARTNER } 1 \\
\text { (Land owner) }\end{array}$ & $\begin{array}{c}\text { PARTNER 2 } \\
\text { (Land Authority or Investor) }\end{array}$ \\
\hline 1. & KSO or JV & $\begin{array}{l}\text { The Company and the Land } \\
\text { Owner entered into a joint } \\
\text { operation agreement which } \\
\text { depends on the area of the land, } \\
\text { a certain area will be built } \\
\text { according to the Master Plan. } \\
\text { For example, business park or } \\
\text { residential. } \\
\text { Participation of each party can } \\
\text { be in the form of: a) Company: } \\
\text { Licensing and management; b) }\end{array}$ & $\begin{array}{l}\text { The Company and the Land } \\
\text { Authority have a joint operation } \\
\text { agreement which depends on } \\
\text { the area of the land will be built } \\
\text { in accordance with the Master } \\
\text { Plan. For example, business } \\
\text { park or residential. } \\
\text { Participation of each party can } \\
\text { be in the form of: a) Company: } \\
\text { Licensing and management; b) }\end{array}$ \\
\hline
\end{tabular}




\begin{tabular}{|c|c|c|c|}
\hline & & $\begin{array}{l}\text { Land Owner: His land (with } \\
\text { alternatives: land rights or } \\
\text { benefits of the land); c) An } \\
\text { appraisal can be made on the } \\
\text { participation of each party to } \\
\text { determine the amount of each } \\
\text { part in the calculation of profit } \\
\text { and loss; d) Each part is agreed } \\
\text { by both parties. }\end{array}$ & $\begin{array}{l}\text { Land Authority: Cash to free } \\
\text { land from the Land Owner; c) } \\
\text { An appraisal can be made on } \\
\text { the participation of each party to } \\
\text { determine the amount of each } \\
\text { part in the calculation of profit } \\
\text { and loss; d) Each part is agreed } \\
\text { by both parties. }\end{array}$ \\
\hline 2. & PP or JE & $\begin{array}{l}\text { The Company and the Land } \\
\text { Owner form a company with } \\
\text { investment: a) Company: } \\
\text { Licensing; b) Land Owner: His } \\
\text { land (with alternatives: land } \\
\text { rights or benefits of the land). } \\
\text { The company can be established } \\
\text { for a certain time. } \\
\text { The parties become the } \\
\text { shareholders of the company } \\
\text { and receive dividends from the } \\
\text { profits of the company's } \\
\text { business management. }\end{array}$ & $\begin{array}{l}\text { The Company and the Land } \\
\text { Authorities or Investors form a } \\
\text { company with the invitation: a) } \\
\text { Company: Licensing; b) Land } \\
\text { Authority: Cash for land } \\
\text { acquisition. } \\
\text { The company can be established } \\
\text { for a certain time. } \\
\text { The parties become the } \\
\text { shareholders of the company } \\
\text { and receive dividends from the } \\
\text { profits of the company's } \\
\text { business management. }\end{array}$ \\
\hline
\end{tabular}

\subsection{Joint Operation (KSO) or Joint Venture (JV)}

In this collaboration pattern, in principle the Company and Investors (both Land Owners and Land Authorities or Investors) poured an agreement in a cooperation agreement with the aim of procuring project land for the development and development of the Kertajati Aerocity Area. Both parties are in a clear position and capacity. The Investor has a number of funds to finance land acquisition, and the Company has a location permit to acquire land, undertake development and development of the area. Both parties can form an agreement in a revenue sharing format, for example 40:60 (Company 40\%: Investor 60\%) when land ownership is transferred to the Company's partners who will use the land. Control over the course of this cooperation can be held by the Company, with the inclusion of these provisions in the agreement [10].

\section{Joint Ventures (PP) or Joint Enterprise (JE)}

In this collaboration pattern, in principle the Company and Investors (both Land Owners and Land Authorities or Investors) form a new company in the form of a PT with the intent and purpose of procuring project land as outlined in the Company's Articles of Association. To form a PT, the parties as shareholders are required to make deposits as income (inbreng). Therefore, the Company as the new shareholder of PT is required to submit income.

Based on Article 1619 Paragraph (2) of the Civil Code jo. Article 34 of the Company Law, income can be paid in cash or other forms. Specifically, for depositing income in other forms determined 
based on fair value determined at market prices or by experts who are not affiliated with the parties and companies to be formed. If the Company has limitations in the provision of cash which will become income, then other forms of non-cash income can be considered. For example, tangible objects and intangible objects that can be valued in money and which have actually been received by the company.

PT BIJB AD as a legal entity mandated by PT BIJB to carry out the development and development of the Kertajati Aerocity Zone, the selection of the most appropriate type or form of cooperation, will certainly relate to the situation of the Company and potential business partners as well as the character of the object of the agreement. As a consideration, it can be seen in the following Table 3:

Table 2: Scheme of Cooperation Relations in the Development and Development of the Kertajati Aerocity Area

\begin{tabular}{|c|c|c|c|}
\hline No. & $\begin{array}{c}\text { Cooperation } \\
\text { Model }\end{array}$ & Development Sector & Prospective Partners \\
\hline 1. & KSO or JV & $\begin{array}{l}\text { Land acquisition, infrastructure } \\
\text { development }\end{array}$ & $\begin{array}{l}\text { Individuals, Non-Legal Entity } \\
\text { Business Entities (Companies, } \\
\text { Firms and CVs), Non-Business } \\
\text { Entity Legal Entities } \\
\text { (Cooperatives, Foundations and } \\
\text { Pension Funds) and Business } \\
\text { Entity Legal Entities (PT) }\end{array}$ \\
\hline 2. & PP or JE & $\begin{array}{l}\text { Land acquisition, procurement of } \\
\text { goods that are general and routine, } \\
\text { for example in the context of } \\
\text { development and development } \\
\text { requires office stationery (ATK), } \\
\text { clean water supply, catering, etc. }\end{array}$ & $\begin{array}{l}\text { Individuals, Non-Legal Entity } \\
\text { Business Entities (Companies, } \\
\text { Firms and CVs), Non-Business } \\
\text { Entity Legal Entities } \\
\text { (Cooperatives, Foundations and } \\
\text { Pension Funds) and Business } \\
\text { Entity Legal Entities (PT) }\end{array}$ \\
\hline 3. & BOT & $\begin{array}{l}\text { Development: infrastructure, } \\
\text { housing, zones according to the } \\
\text { Master Plan }\end{array}$ & $\begin{array}{l}\text { Non Legal Entity Business } \\
\text { Entity (CV), Non Business } \\
\text { Entity Legal Entity } \\
\text { (Cooperatives, Foundations and } \\
\text { Pension Funds) and Business } \\
\text { Entity Legal Entity (PT) }\end{array}$ \\
\hline 4. & $\mathrm{BOO}$ & $\begin{array}{l}\text { Development: infrastructure, } \\
\text { housing, zones according to the } \\
\text { Master Plan }\end{array}$ & $\begin{array}{l}\text { Non Legal Entity Business } \\
\text { Entity (CV), Non Business } \\
\text { Entity Legal Entity } \\
\text { (Cooperatives, Foundations and } \\
\text { Pension Funds) and Business } \\
\text { Entity Legal Entity (PT) }\end{array}$ \\
\hline 5. & BOOT & $\begin{array}{l}\text { Development: infrastructure, } \\
\text { housing, zones according to the } \\
\text { Master Plan }\end{array}$ & $\begin{array}{l}\text { Non Legal Entity Business } \\
\text { Entity (CV), Non Business } \\
\text { Entity Legal Entity } \\
\text { (Cooperatives, Foundations and }\end{array}$ \\
\hline
\end{tabular}




\begin{tabular}{|c|c|c|c|}
\hline & & & $\begin{array}{l}\text { Pension Funds) and Business } \\
\text { Entity Legal Entity (PT) }\end{array}$ \\
\hline 6. & TKA & $\begin{array}{l}\text { Development: infrastructure, } \\
\text { housing, zones according to the } \\
\text { Master Plan }\end{array}$ & $\begin{array}{l}\text { Non Legal Entity Business } \\
\text { Entity (CV), Non Business } \\
\text { Entity Legal Entity } \\
\text { (Cooperatives, Foundations and } \\
\text { Pension Funds) and Business } \\
\text { Entity Legal Entity (PT) }\end{array}$ \\
\hline 7. & TA & $\begin{array}{l}\text { Development: infrastructure, } \\
\text { housing, zones according to the } \\
\text { Master Plan }\end{array}$ & $\begin{array}{l}\text { Non Legal Entity Business } \\
\text { Entity (CV), Non Business } \\
\text { Entity Legal Entity } \\
\text { (Cooperatives, Foundations and } \\
\text { Pension Funds) and Business } \\
\text { Entity Legal Entity (PT) }\end{array}$ \\
\hline 8. & Franchise & $\begin{array}{l}\text { Supplying supermarkets (through } \\
\text { supermarket chains that are in line } \\
\text { with targeted consumer classes: } \\
\text { Alfamart, Indomaret, Yogya or } \\
\text { Griya, Giant, Carefour, etc.), hotels } \\
\text { or guest houses (through hotel chains } \\
\text { that suit targeted consumers: ibis, } \\
\text { sheraton, hilton, etc). }\end{array}$ & $\begin{array}{l}\text { Non Legal Entity Business } \\
\text { Entity (CV), Non Business } \\
\text { Entity Legal Entity } \\
\text { (Cooperatives, Foundations and } \\
\text { Pension Funds) and Business } \\
\text { Entity Legal Entity (PT). }\end{array}$ \\
\hline 9. & Leasing & $\begin{array}{l}\text { The need for goods for capital needed } \\
\text { in construction and development. For } \\
\text { example machinery for road } \\
\text { maintenance, piping, electricity, etc. }\end{array}$ & $\begin{array}{l}\text { Non Legal Entity Business } \\
\text { Entity (CV), Non Business } \\
\text { Entity Legal Entity } \\
\text { (Cooperatives, Foundations and } \\
\text { Pension Funds) and Business } \\
\text { Entity Legal Entity (PT) }\end{array}$ \\
\hline 10. & Partnership & $\begin{array}{l}\text { Development: infrastructure, } \\
\text { housing, zones according to the } \\
\text { Master Plan }\end{array}$ & $\begin{array}{l}\text { Non Legal Entity Business } \\
\text { Entity (CV), Non Business } \\
\text { Entity Legal Entity } \\
\text { (Cooperatives, Foundations and } \\
\text { Pension Funds) and Business } \\
\text { Entity Legal Entity (PT) }\end{array}$ \\
\hline
\end{tabular}

For example, for the construction and development of infrastructure in KKA, it can be considered in the form of BOT, BOO, BOOT, and Turn-key Agreement. For land acquisition, consider KSO or PP form. To build a network with MSMEs, a partnership can be chosen.

\subsection{Investment Scheme in Kertajati Aerocity Development in Majalengka Regency, West Java, which Oriented Good Corporate Governance Principles}

The investment scheme that can be established between PT BIJB and investors (land lords) above, needs to be accompanied by other important considerations relating to aspects of Good Governance, both those that include Good Government Governance and Good Corporate Governance. 


\section{Good Government Governance}

The development and development of the Kertajati Aerocity Area is carried out by referring to the RPJPN, RPJMN, RPJPD and RPJMD which must be implemented by the Government of West Java Province with orientation to good governance or good government governance. In the paradigm of the Law of Economic Development, the government can interfere with the economic activities of the community and the state through two main roles, namely as a regulator and business actors [11].

In connection with the term good government governance (or abbreviated as GGG), it needs to be said beforehand that the use of the term in the community is still ambiguous and there is no plenary agreement to use a standard term. The emergence of the terms good governance, good government, and clean government in principle refers to the same concept and understanding that the government runs its governance with reference to good, clean and fair values [12]. This means that the investment scheme to be carried out by the government as one of the important actors in the development and development of the Aerocity Kertajati area must be in accordance with good, clean and fair values.

The World Bank states that "good governance is the manner in which power is exercised in the management of a country's economic and social resources for development". This originated from The World Bank's attention to the sustainability of projects run by The World Bank relating to financial aspects. In the view of The World Bank, sustainable development can only be realized if within the framework of all regulations and institutions there is transparency, openness, policies that provide enlightenment and predictability, especially in conducting private and public business. The United Nations Development Planning (UNDP) states that good governance is the practice of applying the authority to manage various state affairs, both politically, economically and administratively at all levels. The concept teaches three pillars of good governance, namely economic governance, political governance, and administrative governance.

GGG practices are closely related to the Development and Development of the Kertajati Aerocity Area. In the plan and practice later, the party that will carry out the mandate to build, develop and manage the Kertajati Area is a company formed by PT BIJB, namely PT BIJB AD which will structurally become a subsidiary of PT BIJB. Although in theory, the subsidiary is not a regionally owned enterprise (BUMD) or is private, but in practice, the historical and hierarchical relationship between PT BIJB and PT BIJB AD makes the status of the subsidiary not independent of compliance with relevant laws and regulations with its parent company. This is closely related to the development and development of the Kertajati Aerocity Region, there is a discourse that the Majalengka Regency will be divided into two parts, namely the Majalengka Regency and the Majalengka Municipality after the West Java International Airport operates and the Kertajati Aerocity Region is formed [13].

In Majalengka Regency Regulation Number 11 Year 2011 concerning Majalengka Regency Spatial Planning Year 2011-2031, it can be seen the position of Kertajati Subdistrict which is the main location for the construction of the West Java International Airport and the Kertajati Aerocity Region. In Chapter IV on the Regency Spatial Structure Plan, Kertajati District is included in the Urban System. The opening door for the development and development of the Kertajati Aerocity Area has been placed in such manner in Article 27 Letter h jo. Article 35 Paragraph (1) Letter b is 
the area designated for BIJB and Kertajati Aerocity. Article 35 Paragraph (3) states that the area designated for BIJB and Kertajati Aerocity is the area of: a) BIJB Development covering approximately 1,800 (one thousand eight hundred) hectares; b) Development of the Kertajati Aerocity area of approximately 3,200 (three thousand two hundred) hectares.

The Regional Regulation on RTRW also stipulates BIJB and Kertajati Aerocity as Provincial Strategic Areas which are located in Majalengka Regency Strategic Areas. As for the provincial strategic area, the general provisions of the zoning regulations apply as follows: a) It is permissible to develop to support the area's activities; b) No changes are made to the overall basic functions; and c) It is permissible to provide facilities and infrastructure.

\section{Good Corporate Governance}

Although PT BIJB is closely affiliated with the Government of West Java Province, due to share ownership, in carrying out its business activities the Company is required to apply good corporate governance practices or good corporate governance as stipulated in Act Number 40 of 2007 concerning Limited Liability Companies (Company Law). Perda No. 22 of 2013 concerning the Establishment of BIJB regulates in Article 21, that in managing business activities, the Company is required to implement the following principles: 1) Improving the performance and productivity of the Company's business; 2) Good corporate governance, which includes: a) Transparency; b) Accountability; c) Responsibility; d) Independence; and e) Justice; 3) Improving the quality of planning, implementation, and control of the Company's business.

As described in the Elucidation Section Perda No. 22 of 2013 concerning the Establishment of BIJB, that what is meant by "good corporate governance" is the principle that directs and controls the Company in order to achieve a balance between the power and authority of the Company in providing accountability to shareholders in particular, and stakeholders in general. Furthermore, what is meant by "transparency" is disclosure of information, both in the decision-making process and in disclosing material and relevant information about the Company. What is meant by "accountability" is the clarity of the functions, structure, systems and accountability of the Company's organs, so that the management of the Company is carried out effectively. "Responsibility" is the suitability and compliance in the management of the Company with sound corporate principles and statutory provisions. "Independence" is a condition where the Company is managed professionally without conflict of interest and influence / pressure from any party that is not in accordance with the provisions of the legislation and sound corporate principles. What is meant by "fairness" is fair and equal treatment in fulfilling the rights of stakeholders that arise based on agreements and statutory provisions.

From a theoretical point of view, basically good corporate governance encompasses three main aspects, namely: results-oriented systems, structures and processes. The governance system includes a number of regulations, policies and provisions that form the basis and guidelines for the implementation of the company's business activities. For example, sets of rules relating to good corporate governance, internal control systems, whistle-blowing systems, e-auctions, etc. The governance structure includes positions that are given functions, duties and authority to carry out a governance system that supports the implementation of good corporate governance. This structure for example, the formation of internal auditors, committees under the Board of Commissioners, Independent Commissioners, external auditors, etc. The results-oriented process 
includes a series of activities from human resources that occupy the structure and run a predetermined system, in order to achieve targeted results. This process can be monitored and assessed through a series of mechanisms, for example audits or assessments by both internal (selfassessment) and external (independent) parties.

In addition, the Regional Regulation of West Java Province Number 13 of 2010 concerning the Development and Development of the West Java International Airport and Kertajati Aerocity states in Article 1 that: "National Airport Arrangement is a national airport system that describes airport planning based on spatial planning, economic growth, regional comparative advantage, natural and geographical conditions, intra and intermodal transport integration, environmental sustainability, aviation safety and security, and integration with other development sectors".

Thus, the practice of good governance becomes a corridor that has been outlined by the relevant laws and regulations for the implementation of the development and development of the Kertajati Area, both for the airport and aerocity areas. In this context, good governance becomes a legal mandate for the West Java Provision Government, PT BIJB which is an extension of the West Java Provincial Government and the Majalengka Regency Government. In discussions between the BIJB Internal Team and the Expert Team, information was obtained that the party that would carry out the development and development of the Kertajati Aerocity Area was PT BIJB Aerocity Development (PT BIJB AD), which was hierarchically established as a subsidiary of PT BIJB. Considering the existence, function and role of PT BIJB AD is inseparable from the existence, function and role of PT BIJB which has the status of a regionally-owned enterprise (BUMD), both directly and indirectly, PT BIJB AD is bound by the obligation to carry out its establishment mandate with pay attention to the rules of good corporate governance. Directly, because PT BIJB $\mathrm{AD}$ is a company that will develop, develop and manage the Kertajati Aerocity Area, it must comply with the Limited Liability Company Law which mandates the obligation to carry out its business activities with reference to good corporate governance. Indirectly, because although PT BIJB AD is a subsidiary of BUMD (PT BIJB) it means that PT BIJB AD is a private company, but considering the purpose of establishing PT BIJB AD is to carry out the development, development and management of the Kertajati Aerocity Area which was previously mandated by Regional Regulations to PT BIJB, PT BIJB AD must represent a generic aspect of the company's performance, which is good corporate governance.

The mandate to carry out good corporate governance practices starts with the Company Law, the Company's Articles of Association, and other relevant laws and regulations, especially those relating to corporate activities in the context of investment. With the establishment of this subsidiary, a group of companies (group companies, group of companies) has been formed in a simple structure: 1 (one) holding company and 1 (one) subsidiary. In the course of each company's business activities, a parent-child relationship mechanism will naturally be developed that needs to be mutually agreed upon.

In some reports in the mass media it has also been reported in connection with the Company's business plans in the future in the context of regional development. Among other things, will create a joint venture (joint enterprise) with a number of partners. In this case, if the joint venture is formed by income from PT BIJB AD, then in a hierarchical structure, there will be additional members from the business group or company of this group. 


\section{Group Governance}

In the context of good governance, in time it is necessary to formulate Group Governance (GG) or also known as Subsidiary Governance (SG). GG or SG is in principle a nexus of contract between the Directors and Board of Commissioners of the parent and subsidiary in achieving the vision of the group and managing the alignment of the parent and subsidiary business. Therefore, it needs to be made in a written document format signed by the Directors and Board of Commissioners of the parent and subsidiary.

The Group Governance document is a guideline for the parent and subsidiary in carrying out the company's business activities to achieve the goals and objectives of each company and group. For example, agreements were made in terms of procurement of goods and services, recruitment and selection of new employees, setting business targets, preparing RKAP, and others. These things will be done by referring to the Good Governance Guidelines which have become a collective agreement. Compliance of each corporate entity to the Guidelines can be preceded by the signing of a kind of integrity pact by the Directors and Board of Commissioners of the parent and subsidiaries which are also witnessed by the Shareholders of each company.

\section{Conclusions}

Investment Scheme in Kertajati Aerocity Development in Majalengka Regency, West Java, namely through cooperation between PT BIJB and investors (land lords) in land acquisition and the relationship of development cooperation and development of Aerocity Kertajati area. Investment Scheme in Kertajati Aerocity Development in Majalengka Regency, West Java Oriented Principles of Good Corporate Governance namely by implementing Good Government Governance, namely the government as one of the parties in its role of building and developing the Aerocity Kertajati area must refer to good values, clean and fair, and Good Corporate Governance must be reflected in the management of PT BIJB's business activities as an extension of the West Java provincial government covering transparency, accountability, responsibility, independence, and justice. The recommendations or suggestions that can be submitted to the parties related to the development and floating of the Aerocity Kertajati area are as follows: a) Considering that the development and development of the Aerocity Kertajati Area will be a longterm project, it is necessary to establish a cooperative relationship based on a vision of more economic development large. The KSO collaboration model can be a strategic choice and is in accordance with the condition of the Company and the current situation on the ground; b) PT BIJB Needs to compile a Roadmap for the agenda to build and develop good governance towards the development of the Aerocity Kertajati area, which is compiled starting from concepts and commitments, activities, parties given relevant tasks, authorities and responsibilities to the schedule its implementation in detail (year and month).

\section{References}

[1] Article 2 West Java Province Regional Regulation Number 13 of 2010 concerning Development and Development of West Java International Airport and Kertajati Aerocity.

[2] Article 3 West Java Province Regional Regulation Number 13 of 2010 concerning Development and Development of West Java International Airport and Kertajati Aerocity.

[3] Aerocity, http://bijb.co.id/ID/aerocity/ diakses pada 25 November 2016. 
[4] Article 25 Regional Regulation West Java Province Number 13 of 2010 concerning Development and Development of West Java International Airport and Kertajati Aerocity.

[5] China Eyes Investment in Kertajati Airport, Tempo Online, 20 Maret 2016, http://en.tempo.co/read/news/2016/03/30/056755313/China-Eyes-Investment-in-Kertajati-Airport diakses pada 26 November 2016.

[6] Kunjungan COMAC dan CALC, situs web BIJB, 18 Februari 2016, http://bijb.co.id/ID/indonesiakunjungan-comac-calc diakses pada 26 November 2016.

[7] China Tertarik Bangun Aerotropolis di BIJB, situs web BIJB, 14 April 2016, http://bijb.co.id/ID/china-interested-to-develop-aerotropolis-bijb/ diakses pada 26 November 2016.

[8] Setiani, B. 2015. Prinsip - Prinsip Manajemen Pengelolaan Bandar Udara. Jurnal Imiah Widya Volume 3 Nomor 1 Januari - Agustus 2015: Jakarta.

[9] Regulation of the Minister of State / Head of National Land Agency Number 2 of 1993 concerning Procedures for Obtaining Location Permits and Land Rights for Companies in the Framework of Investment and Decree of the State Minister of Agrarian / Head of National Land Agency Number 22 of 1993 concerning Guidelines for Implementing Location Permit in the Context of Implementation of Minister of State Regulation / Head of National Land Agency Number 2 of 1993 concerning Procedures for Obtaining Location Permit and Land Rights for Companies in the Framework of Investment.

[10] Crider, R., Preisler, M., Autin, E., Roth, S., Fulton, S., Swartzlander, J., et. Al. (2011). Guidebook For Developing and Leasing Airport Property. Transportation Research Board: Washington, DC.

[11] Direktorat Jenderal Perbendaharaan. 2013. Manual Pengelolaan Satker BLU Bidang Layanan Barang dan/atau Jasa Lainnya. Kementerian Keuangan: Jakarta.

[12] Mazzucato, M. 2011. The Entrepreneurial State. Mixed Source: London.

[13] www.pikiran-rakyat.com/jawa-barat/2017/02/26/kertajati-aero-city-terbentuk-majalengka-akandibagi-kabupaten-kota-394587

\footnotetext{
*Corresponding author.

E-mail address: ratnajanuarita.unisba@ gmail.com
} 